\title{
УДК: 616.311.2-002.2-08
}

\section{PECULIARITIES OF THE CLINICAL COURSE OF GENERALIZED PERIODONTITIS IN PATIENTS WITH ISCHEMIC HEART DISEASE ОСОБЛИВОСТІ КЛІНІЧНОГО ПЕРЕБІГУ ГЕНЕРАЛІЗОВАНОГО ПАРОДОНТИТУ У ХВОРИХ НА ІШЕМІЧНУ ХВОРОБУ СЕРЦЯ}

Lebid O.I / Лебидь O.I. c.m.s, as. prof. / к.м.н., доцент Duda K.M. / Дуда К.М. c.m.s, as. prof. / к.м.н., дочент Ternopil National Medical University by I. Gorbachevsky Ministry of Health of Ukraine Ternopil, Chehova 7, 46000

Анотація: Метою даної роботи було виявити особливості клінічного перебігу генералізованого пародонтиту у хворих на ішемічну хворобу серия. Для досягнення поставленої мети було проведено клінічне стоматологічне обстеження. Згідно результатів проведених досліджень щзодо особливостей клінічного перебігу генералізованого пародонтиту у хворих на ішемічну хворобу серия виявлено, шчо пацієнтів із ГП на фоні ІХС спостерігалась достовірно вища втрата зубів ніж у пацієнтів із ГП без IXC

Ключові слова: пародонтит ішемічна хвороба серия, карієс, клиновидні дефекти, патологічне стирання.

\section{Вступ.}

Хвороби пародонта займають друге місце за поширеністю серед стоматологічних захворювань. Генералізований пародонтит - найпоширеніший вид патології пародонта, особливо у другій половині життя людини. Висока поширеність, схильність до прогресування i багатогранний вплив на зубощелепну систему, й організм у цілому, а також неоднозначність лікування дозволяють віднести захворювання пародонта до числа актуальних проблем сучасної медицини $[1,2,4,6]$. Це диктує необхідність пошуку оптимальних шляхів профілактики та лікування з урахуванням патогенетичних механізмів. Установлений тісний зв'язок патології пародонта з загальними захворюваннями організму, особливе місце серед яких займає серцево-судинна патологія, найчастіше - ішемічна хвороба серця (IXC) [3,5,7]. Повідомляється про наявність спільних ланок патогенезу, зокрема розвитку як у серцевому м'язі, так і у тканинах пародонта гіпоксичного та вільнорадикального некробіозу $[4,6,8]$. Згідно з експертними оцінками ВОО3, ішемічна хвороба серця - одне 3 найпоширеніших захворювань і одна 3 основних причин смертності, а також тимчасової та стійкої втрати працездатності населення в розвинених країнах світу. За останні 10 років в Україні поширеність і захворюваність на IXC виросли у 2 рази (Чумакова Ю.Г., 2007; Борисенко А.В., 2010). Розвиток IXC в значній кількості випадків (від 80 до 92\%) супроводжується проявами в порожнині рота (Humphrey L.L., 2008; Thomopoulos C., 2011).

\section{Результати досліджень.}

Для визначення особливості перебігу генералізованого пародонтиту у пацієнтів із ішемічною хворобою серця в дослідження було включено 154 хворих і розподілено на 2 групи. До I групи ввійшли 99 пацієнтів із ГП та IXC віком 44,72 $\pm 5,53$ років, а до II групи (порівняння) ввійшло 55 пацієнти із ГП без 


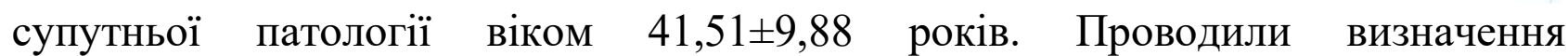
стоматологічного статусу (втрата зубів, розповсюдженості дефектів зубних рядів, наявність травматичної оклюзії, розповсюдженість та інтенсивність карієсу зубів, наявність патологічного стирання, клиновидних дефектів та гіперестезії зубів) у даних пацієнтів.

Результати дослідження кількості втрачених зубів продемонстрували, що у пацієнтів із ГП з IXC втрата зубів була достовірно вища $(p<0,05)$, порівняно із пацієнтами з групи порівняння без IXC. Кількість втрачених зубів у пацієнтів I

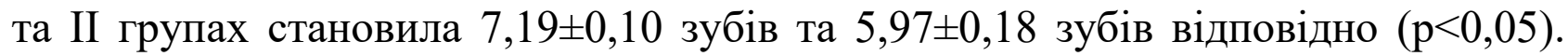
Більша втрата зубів у пацієнтів I групи призвела до більшої розповсюдженості дефектів зубних рядів у даних пацієнтів $(55,83 \pm 2,18 \%)$, порівняно із пацієнтами II групи $(31,01 \pm 1,02 \%)(\mathrm{p}<0,05)$.

Результати визначення наявності травматичної оклюзії у пацієнтів по групах продемонстрували, що у пацієнтів I групи була вища поширеність травматичної оклюзії, порівняно із пацієнтами II групи та становила 85,5 \%. Поширеність травматичної оклюзії у пацієнтів II групи становила 64,8\%. Однак не було виявлено достовірної різниці між групами ( $>>0,05)$. Проводили визначення розповсюдженості та інтенсивності карієсу по групах. Карієс зубів наявний у всіх пацієнтів I та II груп (100,0 \% розповсюдженість). Однак у пацієнтів I групи інтенсивність карієсу $(13,76 \pm 0,10)$ була достовірно вищою $(\mathrm{p}<0,05)$, ніж у пацієнтів II групи $(11,47 \pm 0,24)$.

Проводили визначення наявності патологічного стирання, клиновидних дефектів та гіперестезії зубів у пацієнтів із ГП по групах. Результати визначення патологічного стирання зубів продемонстрували, що у пацієнтів I групи $(71,58 \%)$ було виявлено достовірно вищу $(p<0,05)$ поширеність патологічного стирання, порівняно із II групою (29,41%). Результати визначення наявності клиновидних дефектів зубів продемонстрували, що у 70,52 \% пацієнтів I групи наявні клиновидні дефекти, а у пацієнтів II групи 54,9 \%. Проводили визначення поширеності підвищеної чутливості зубів до дії різних подразників. Виявили, що у пацієнтів I групи була достовірно вища $(\mathrm{p}<0,05)$ поширеність підвищеної чутливості зубів, порівняно із пацієнтами II групи та становила 61,5 \%. Поширеність підвищеної чутливості зубів у пацієнтів II групи становила 27,41\%.

\section{Висновок.}

Отже, у пацієнтів із ГП на фоні IXC спостерігалась достовірно вища втрата зубів ніж у пацієнтів із ГП без IXC, що призвела до більшої розповсюдженості дефектів зубних рядів. Внаслідок цього в даних пацієнтів виявлено достовірно вищі показники патологічного стирання зубів та гіперестезії зубів. Також у даних пацієнтів була виявлена вища поширеність травматичної оклюзії.

\section{Література:}

1. Бартенева Т. В. Лечение и профілактика заболеваний пародонта у пациентов с ишемической болезнью сердца : автореф. дис. на здобуття наук. ступеня канд. мед. наук: спец. 14.00.21 - Стоматологія /Т. В. Бартенева. Волгоград, 2008. - 18 с. 
2. Білоклицька Г. Ф. Моніторинг інноваційного забезпечення за напрямом «стоматологія» у сфері охорони здоров'я україни за 2009- 2014 роки / Г. Ф. Білоклицька, А. С. Горбань, Л. І. Закрутько [та ін.] // Вісник соціальної гігієни та організації охорони здоров’я України. - 2015. - № 3 (65). - С. 49-53.

3. Мазур I. П. Сучасний стан стоматологічної допомоги в Україні / I. П. Мазур, О. В. Павленко // Здоров’я України. - 2017. - № 18 (415). - С. 74- 75.

4. Павленко О. В. Шляхи реформування системи надання стоматологічної допомоги населенню України / О. В. Павленко, О. М. Вахненко // Сучасна стоматологія. - 2013. - № 2. - С. 180-181.

5. Шилівський I. В. Сучасні погляди на етіологію та патогенез запальних захворювань пародонта, їх взаємозв'язок із патологією сечовидільної системи (огляд літератури та власні дослідження) / І. В. Шилівський, О. М. Немеш, 3. М. Гонта // Буковинський медичний вісник. - 2016. - Т. 20, № 1 (77). - С. 224-227.

6. Diomedi M. The role of chronic infection and inflammation in the pathogenesis of cardiovascular disease / M. Diomedi, G. Zeone, A. Renna // Timely Top Med Cardiovasc Dis. - 2006. - № 10:E6.

7. Mattila K. J. Association between dental health and acute myocardial infarction / K. J. Mattila, M. S. Nieminen, V. V. Valtonen [et al.] // BMJ. - 1989. № 298. - P. 179-781.

8. Monterio A. M. Cardiovascular diseases parameters in periodontitis / A. M. Monterio, M. A. Jardini, S. Alves [et al.] // J.Periodontal. - 2009. - № 11. - Vol. 80, № 3. - P. 378-388.

\section{References:}

1. Barteneva T. V. Lechenye y profylaktyka zabolevanyya parodonta $\mathrm{u}$ patsyentov $\mathrm{s}$ yshemycheskoy bolezn'yu serdtsa: avtoref. dys. na zdobuttya nauk. stupenya kand. med. nauk: spets. 14.00.21 - Stomatolohiya / T. V. Barteneva. - Volhohrad, 2008. - 18 s.

2. Biloklits'ka H. F. Monitorynh innovatsiynoho zabezpechennya za napryamkom «stomatolohiya» u sferi okhorony zdorov"ya ukrayiny za 2009- 2014 roky / H. F. Biloklits'ka, A. YE. Horban', L. I. Zakrut'ko [ta in.] // Visnyk sotsial'noyi hihiyeny ta orhanizatsiyi okhorony zdorov"ya Ukrayiny. - 2015. - № 3 (65). - S. 49-53.

3. Mazur I. P. Suchasnyy stan stomatolohichnoyi dopomohy v Ukrayini / I. P. Mazur, O. V. Pavlenko // Zdorov"ya Ukrayiny. - 2017. - № 18 (415). - S. 74- 75.

4. Pavlenko O. V. Shlyakhy reformuvannya system nadannya stomatolohichnoyi dopomohy naselennyu Ukrayiny / O. V. Pavlenko, O. M. Vakhnenko // Suchasna stomatolohiya. - 2013. - № 2. - S. 180-181.

5. Shylivs'kyy I. V. Suchasni pohlyady na etiolohiyu ta patohenez zapal'nykh zakhvoryuvan' parodontu, yikh vzayemozv'yazok iz patolohiyeyu sechovydil'noyi systemy (ohlyad literatury ta vlasni doslidzhennya) / I. V. Shylivs'kyy, O. M. Nemesh, Z. M. Honta // Bukovyns'kyy medychnyy visnyk. - 2016. - T. 20, № 1 (77). - S. 224-227.

6. Diomedi $M$. The role of chronic infection and inflammation in the pathogenesis of cardiovascular disease / M. Diomedi, G. Zeone, A. Renna // Timely Top Med Cardiovasc Dis. 2006. - № 10:E6.

7. Mattila K. J. Association between dental health and acute myocardial infarction / K. J. Mattila, M. S. Nieminen, V. V. Valtonen [et al.] // BMJ. - 1989. - № 298. - P. 179-781.

8. Monterio A. M. Cardiovascular diseases parameters in periodontitis / A. M. Monterio, M. A. Jardini, S. Alves [et al.] // J.Periodontal. - 2009. - № 11. - Vol. 80, № 3. - P. 378-388. 
Abstract: The aim of this work was to identify the features of the clinical course of generalized periodontitis in patients with coronary heart disease. To achieve this goal, clinical dental examinations were performed. According to the results of studies on the clinical course of generalized periodontitis in patients with coronary heart disease, it was found that patients with GP on the background of coronary heart disease had a significantly higher loss of teeth than in patients with GP without coronary heart disease.

Key words: periodontitis ischemic heart disease, caries, wedge-shaped defects, pathological abrasion. 